\title{
A cclimation trials of juvenile Italian sturgeon to different salinities: morpho-physiological descriptors
}

\author{
E. Cataldi*, E. Ciccotti* P. D i marco*, O. D i Santo*, P. Bronzi† and \\ S. Cataudella* \\ *D epartment of Biology, U niversity of R ome T or V ergata, via della Ricerca Scientifica, \\ 00133 Rome and tENEL ( DSR CRTN) via M onfalcone 15, M ilan, Italy
}

(Received 31 M ay 1994, A ccepted 11 D ecember 1994)

\begin{abstract}
In this study the first experimental trials of acclimation to salinities of the Italian sturgeon Acipenser naccarii are described. Preliminary observations regarding some morphological features of the gut, kidney and gills following exposure to 20 and $30 \%$ salinity are reported, and compared with those displayed by many teleosts in hyper- and hypoosmoregulation. R esults are discussed with regard to the osmoregulatory mechanisms and to the physiological limits of adaptability of this species in the second year of its life cycle. Within the Acipenseridae, A cipenser naccarii is generally considered a euryhaline species, but nothing is known about its mechanisms of osmotic homeostasis. This species could be a good candidate for aquaculture in fresh and brackish waters owing to the recent success obtained in artificial reproduction.
\end{abstract}

(C) 1995 The Fisheries Society of the British Isles

K ey words: osmoregulation; saltwater adaptability; Acipenser naccarii; oesophagus; kidney; gills.

\section{INTRODUCTION}

The Italian sturgeon Acipenser naccarii Bonaparte, a species about whose biology comparatively little is known (Tortonese, 1989), was once abundant in all the rivers tributary to the $\mathrm{N}$ orth $\mathrm{A}$ driatic Sea. Today its distribution range has been greatly reduced, owing to the impact of factors such as pollution and overfishing. Interest in this species was aroused recently by the success obtained in artificial reproduction (A rlati et al., 1988), which suggests that A . naccarii may be suitable both for fish farming and for restocking.

A . naccarii must be a euryhaline fish as it is found in the sea although it breeds in fresh water (Tortonese, 1989; Bernini \& Nardi, 1990; Rossi et al., 1992). H owever, when in the sea, the I talian sturgeon seems to remain near the estuaries (Paccagnella, 1948). R ochard et al. (1990) identified three types of life history for the sturgeons and assigned the Italian species to type 2. A fter spawning, the adults migrate to brackish waters, later followed by the juveniles. In a later work, Rochard et al. (1991) defined this sturgeon as a mainly freshwater species.

$\mathrm{K}$ nowledge of the ability of the I talian sturgeon to adapt to salinity variations is of particular interest in relation to its estuarine ecology and to aquaculture development. If its euryhalinity is ascertained, this could open up the way to extensive culture of sturgeons in low salinity environments, which are abundant in the north of Italy, where Adriatic 'Vallicoltura', an extensive culture in brackish lagoons, plays an important role. 
In general, little is known about the mechanisms of osmotic homeostasis in sturgeons. Some R ussian species seem to have a narrow range of euryhalinity (Shelukin et al., 1990; $\mathrm{N}$ atochin et al., 1985). Few morphological studies have described cell and tissue features in relation to the osmoregulatory function. Organs involved in osmoregulation in teleosts are kidney, gills and digestive tract. Their morphofunctional features have been described in fishes under different natural and experimental conditions of salinity, and used to evaluate the adaptability of the different species. F or the first time an experimental acclimation of the Italian sturgeon to varying salinity was achieved and is described in the present paper. Preliminary observations on structural adaptive changes of gut, gills, and kidney are compared with those displayed by many teleosts in order to gain initial insight into the adaptability of this species and its osmoregulatory mechanisms.

\section{MATERIALS AND METHODS}

\section{ACCLIMATION}

Juveniles of $A$. naccarii from artificial reproduction were used. Considering the difficulties in finding this species and maintaining such large animals in acceptable experimental conditions, only a small number of fishes was used.

Trial 1

During autumn 1992, two fishes (14 months old, $932 \pm 101 \mathrm{~g}$ ) were acclimated gradually from fresh water ( $F$ W: $0 \%, 7.5 \mathrm{mO} \mathrm{sm} \mathrm{kg}^{-1}$ ) to artificial brackish water (BW: $20 \%$, $689 \mathrm{mO} \mathrm{sm} \mathrm{kg}^{-1}$ ) in closed $400 \mathrm{I}$ aquaria equipped with filters (10 I) and having a water turnover of $1500 \mathrm{I} \mathrm{h}^{-1}$. Temperature was maintained at $20^{\circ} \mathrm{C}$. Fish were maintained at $20 \%$ salinity for 15 days.

\section{Trial 2}

In spring 1993, six fishes (20 months old, $1.9 \pm 0.2 \mathrm{~kg}$ ) were acclimated from FW $\left(0 \%, 7.5 \mathrm{mOsm} \mathrm{kg}{ }^{-1}\right)$ to natural BW $\left(20 \%, 664 \mathrm{mOsm} \mathrm{kg}^{-1}\right)$ in a closed $3 \mathrm{~m}^{3}$ raceway equipped with a filter room $\left(0 \cdot 4 \mathrm{~m}^{3}\right)$ and having a water turnover of $3500 \mathrm{I} \mathrm{h}^{-1}$. Temperature was maintained at $20^{\circ} \mathrm{C}$. A fter a month at $20 \%$, salinity was gradually increased to $30 \%$ (SW : $945 \cdot 3 \mathrm{mO} \mathrm{sm} \mathrm{kg}{ }^{-1}$ ). In both trials, final salinities were reached in steps of $3 \%$ increases per day.

During the acclimation phases, fish were starved and then fed once a day with commercial pellet food. Dissolved oxygen, ammonium, nitrites and nitrates were kept under control. F or both trials, controls in F W were maintained at the same experimental conditions.

A cclimated specimens were examined at the end of Trial 1. In Trial 2 they were examined after the period in BW and after 15 and 60 in SW. FW controls were examined as well. Fish were anaesthetized ( $3 \mathrm{ppm}$ 2-phenoxy-ethanol) and blood samples were obtained directly from the heart. Gills, oesophagus and kidney were fixed for light microscopy.

\section{SAM PLE PROCESSING}

Blood was centrifuged at $3000 \mathrm{rpm}$ for $10 \mathrm{~min}$. Serum osmolality was determined by the cryoscopic method (One-ten Osmometer, Fiske). Electrolyte composition was measured. $\mathrm{Na}^{+}$and $\mathrm{K}^{+}$were determined by flame photometry (GDV Digiflame 2000 with air butane flame). $\mathrm{Cl}^{-}$concentration was measured by the mercuric thiocyanate method (Iwasaki et al., 1952). 
TABLE I. I onic concentrations and osmolality values (means) of plasma in freshwater-, brackish water- and seawater-acclimated A. naccari in the two trials

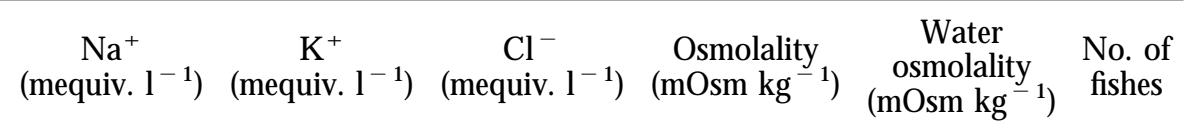

\begin{tabular}{|c|c|c|c|c|c|c|}
\hline \multicolumn{7}{|l|}{ Trial 1} \\
\hline FW & $140 \cdot 7$ & 3.6 & $126 \cdot 1$ & $285 \cdot 2$ & $13 \cdot 0$ & 7 \\
\hline BW & $166 \cdot 0$ & $2 \cdot 2$ & $172 \cdot 5$ & $352 \cdot 1$ & $674 \cdot 2$ & 2 \\
\hline \multicolumn{7}{|l|}{ Trial 2} \\
\hline FW & $142 \cdot 2$ & $3 \cdot 7$ & $137 \cdot 1$ & $290 \cdot 9$ & $12 \cdot 0$ & 5 \\
\hline BW & $146 \cdot 5$ & 3.8 & $154 \cdot 5$ & $292 \cdot 3$ & $666 \cdot 5$ & 2 \\
\hline SW (15 days) & $155 \cdot 0$ & 3.8 & $209 \cdot 0$ & $303 \cdot 7$ & $951 \cdot 0$ & 1 \\
\hline SW (60 days) & $141 \cdot 0$ & 3.0 & 133.5 & $320 \cdot 0$ & $951 \cdot 0$ & 2 \\
\hline
\end{tabular}

K idney and gut were fixed for light microscopy in D ubosq-Brazil liquid, dehydrated, embedded in paraffin and cut to $7 \mu \mathrm{m}$. Sections were then stained with haematoxylineosin and A Ician blue. Filaments of the second gill arch were fixed for $20 \mathrm{~h}$ in osmium tetroxide and zinc iodide 2:8 according to G arcia-R omeu \& M asoni (1970). After rinsing and embedding in paraffin, the filaments were sectioned to a thickness of $5 \mu$. No staining followed, as this fixative stains chloride cells selectively.

\section{MEASUREMENTS}

Glomerular volumes and surfaces were measured by means of image analysis (QU A N TIM ET 970, Cambridge Instruments). N on-parametric (K ruskal-Wallis) oneway analysis of variance was performed on glomerular measurements to detect significant differences between the two acclimation conditions.

Chloride cell counts were made on histological sections of filaments at corresponding levels, i.e. when the section of a cartilaginous projection of the gill ray appeared in the middle of a filament. T wo separate kinds of cells were considered: (1) cells located on both lamellae and interlamellar spaces, contacting the lamellar vessel (L); and (2) cells located in the interlamellar spaces, and extending towards the filament vessels (S). F or each fish, 168 lamellae and 112 interlamellar spaces were examined.

\section{RESULTS}

D uring both the acclimation trials, A. naccarii showed normal swimming and feeding activities. No mortalities were recorded in Trial 1, while one specimen died after a few days in BW in Trial 2.

\section{SERUM}

The sturgeons, hyperosmotic to FW, were hypoosmotic to BW and SW (Table I). Comparisons of electrolyte composition in individual fishes showed that the levels of $\mathrm{N} \mathrm{a}^{+}$and $\mathrm{Cl}^{-}$concentrations were independent of osmolality values. In Trial 1 osmolality values of BW-adapted sturgeons were much higher than in FW-adapted specimens; in Trial 2 higher values were observed only in SW-adapted fishes. A progressive increase can be observed in connection with the acclimation duration. 
GUT

The mucosa of the short oesophagus was organized into distally oriented papillae. The epithelium was stratified throughout. The first portion was rich in mucous cells, and many taste buds were present. A fter acclimation to BW and SW, the oesophageal epithelium maintained the same structure. No structural changes were observed on examining the intestine except for some degenerative aspects in sturgeons kept for 60 days in SW. The latter presented an intestine that was highly dilated by a large volume of luminal fluid, that was slightly hypoosmotic to serum.

\section{KIDNEY}

The nephron of FW A. naccarii [Fig. 1(a)] consisted of a corpuscle with a highly vascularized, often multilobed glomerulus, a short neck segment, two proximal tubule segments, distinguishable by the different heights of the cells and of the brush border, a long distal segment and the collecting tubule connected to the system of collecting ducts. Following exposure to BW, a significant decrease $(P<0.001)$ for both glomerular surface and volume was observed (Table II). Light microscopy observation showed only a reduction in the vascular supply to the glomeruli. A fter 60 days in SW [F ig. 1(b)], most glomeruli appeared further reduced, even if the decrease in size was not quantified, while vascularization was often absent. F urthermore, the examination of serial sections showed that empty capsules were present, without glomeruli. Cells of the tubules were lower than in FW, and were cuboidal or flat. The brush border also was lower and sparser. It was often difficult to distinguish among the different regions of the tubules. M oreover, many cells showed nuclear degeneration.

\section{GILLS}

Chloride cells [Fig. 2(a)] were present on the secondary lamellae and in the interlamellar region of the filament (primary lamella). They were scarce or absent on the afferent and efferent edges of the filament. On the lamellae, cells were generally round in shape, protruding from the epithelium. In the interlamellar region of the filament, chloride cells were pear-shaped or cylindrical. The cells located on the sides of the space were in contact with the lamellar vessels, while the central ones seemed to extend towards the filament vessels. A fter acclimation to both salinities [F ig. 2(b)], the lamellar chloride cells more often appeared flattened. A decrease in the number of the lamellar chloride cells is evident in BW-adapted sturgeons in both trials (Table III), while for the interlamellar chloride cells the differences between individuals overlapped the differences between the two acclimation conditions.

\section{DISCUSSION}

In SW, teleosts compensate for osmotic water losses by drinking and desalting water in the oesophagus and absorbing it in the intestine ( $\mathrm{K}$ irsch et al., 1984). Passive and/or active transport of ions from the mucosal to serosal side of the oesophagus is made possible by the fact that in SW a simple columnar epithelium, consisting of transporting type cells, replaces the stratified freshwater 

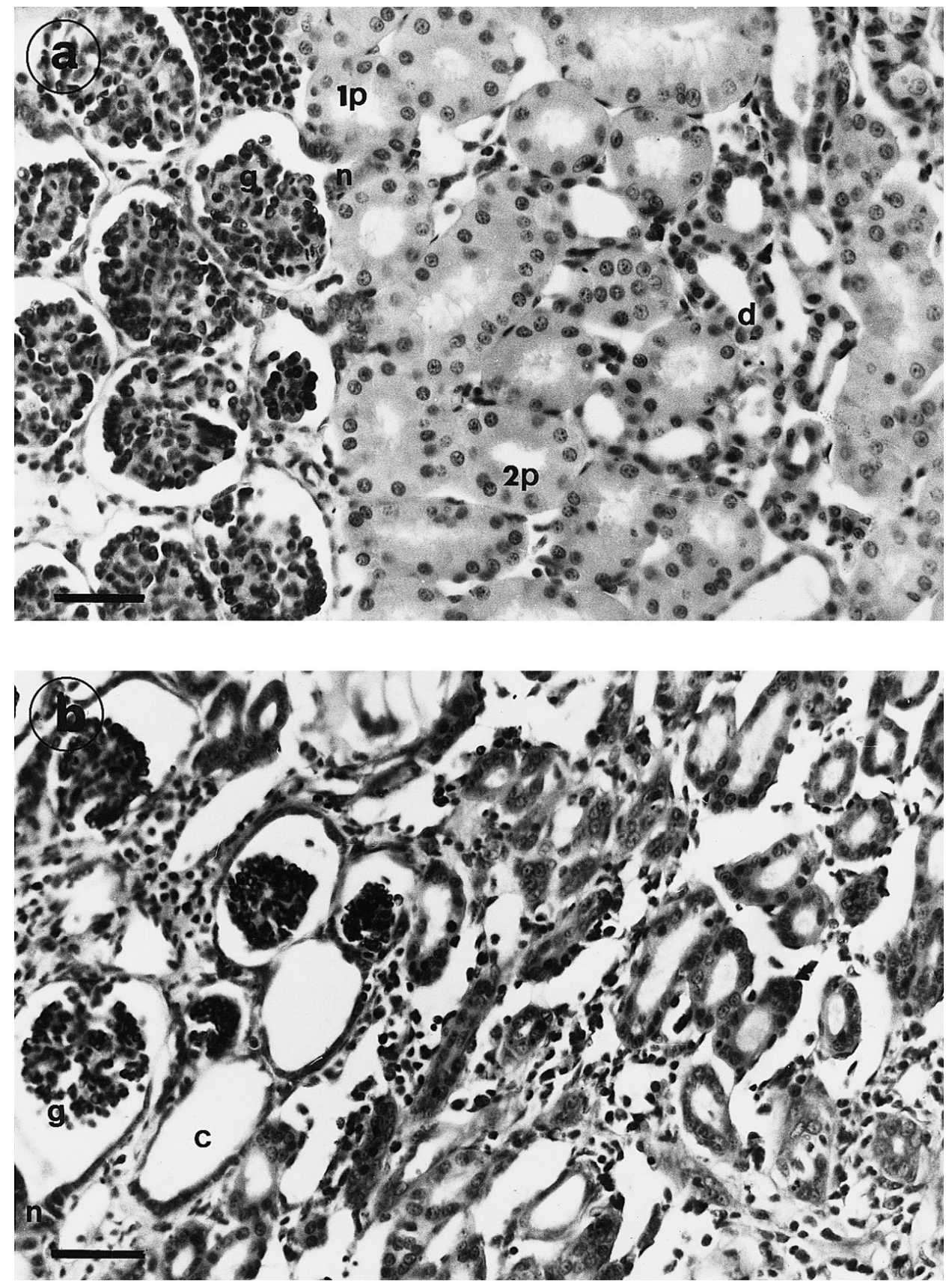

F IG. 1. Cross-section of kidney of A cipenser naccarii (a) living in fresh water (b) acclimated to sea water from 60 days. g, Glomerulus; $n$, neck segment; $1 p, 2 p$, first and second proximal tubules; $d$, distal segment; c, capsule without glomerulus. Scale bar, $50 \mu \mathrm{m}$.

oesophageal mucosa. In A nguilla anguilla L. (Y amamoto \& H irano, 1978), and in O reochromis mossambicus Peters (Cataldi et al., 1988a,b) considerable changes are already evident after 7 days in SW. The oesophageal epithelium of A cipenser 
TABLE II. Glomerular surface and volume of nephrons (mean \pm S.D.) of freshwater- and brackish water-acclimated A. naccari in the two trials (no measures were performed on the seawater-acclimated specimens)

\begin{tabular}{cccc}
\hline & $\begin{array}{c}\text { Surface } \\
\left(\mu \mathrm{m}^{2}\right)\end{array}$ & $\begin{array}{c}\text { Volume } \\
\left(\mu \mathrm{m}^{3}\right)\end{array}$ & $\begin{array}{c}\text { No. of } \\
\text { glomeruli } \\
(\mathrm{N} \text { o. of fishes })\end{array}$ \\
\hline Trial 1 & & & \\
FW & $30576 \pm 9680$ & $489999 \pm 218644$ & $17(2)$ \\
BW & $14906 \pm 2531$ & $155526 \pm 43346$ & $15(2)$ \\
Trail 2 & & & $10(1)$ \\
FW & $18924 \pm 3918$ & $222088 \pm 61858$ & $14(2)$ \\
BW & $12372 \pm 1581$ & $122067 \pm 24048$ & \\
\hline
\end{tabular}

naccarii did not show any modifications even after 60 days in SW. The abnormal fluid content observed in the posterior intestine could be sea water ingested, not desalted in the oesophagus and diluted by osmotic losses from tissues. Water ingestion is induced in fish, even in stenohaline freshwater fishes ( $L$ ahlou et al., 1969), by the transfer to a hypertonic medium (H irano, 1974). The two-step scheme of the mechanism responsible for water recovery in teleosts cannot apply to sturgeons: from these preliminary observations it is not possible to say how water balance, that took place somehow as the fishes did survive, is carried out in the sturgeons.

In SW, teleosts reduce the amount of urine excreted. A decrease in glomerular size was observed in many euryhaline teleosts acclimated experimentally to higher salinities (Wendelaar Bonga, 1973; Oliverau \& Oliverau, 1977; Colville et al., 1983; Cataldi et al., 1991; Cataudella et al., 1991). A decrease in nephron size was observed in BW -adapted A. naccarii, in agreement with observations on wild $A$. gueldenstaedti Brandt from sea and from inland waters (Gambaryan, 1988). H owever, in 60 day-SW-acclimated sturgeons the degenerative features observed in the whole nephron were similar to those observed in Oreochromis niloticus $L$. and 0 . mossambicus, which displayed a low degree of salt tolerance (Cataldi et al., 1991).

The SW teleosts excrete ions in excess through chloride cells. An increased number and/or size of the interlamellar chloride cells is described for euryhaline teleosts during adaptation to SW (L aurent \& H ebebi, 1989; Cioni et al., 1991; A vella et al., 1993). On the other hand, a degeneration and disappearance of lamellar chloride cells, that are linked to the ion pumping capacity of the gill in FW, was reported for the A tlantic salmon during its migration to the sea (Bornacin et al., 1987). The possible coexistence of two chloride cell types with different functions linked to different compartments of the circulatory system was debated recently (Laurent \& Perry, 1991). A basic pattern of the gill vascular organization in teleosts and chondrosteans was demonstrated ( $D$ unel \& Laurent, 1978). As far as sturgeons are concerned, K rayushkina et al. (1976) describe for $\mathrm{H}$ uso huso L., a generic increase of chloride cells after 5 days of acclimation at $12 \cdot 5 \%$ salinity, and L aurent \& Dunel (1980) report an increase 

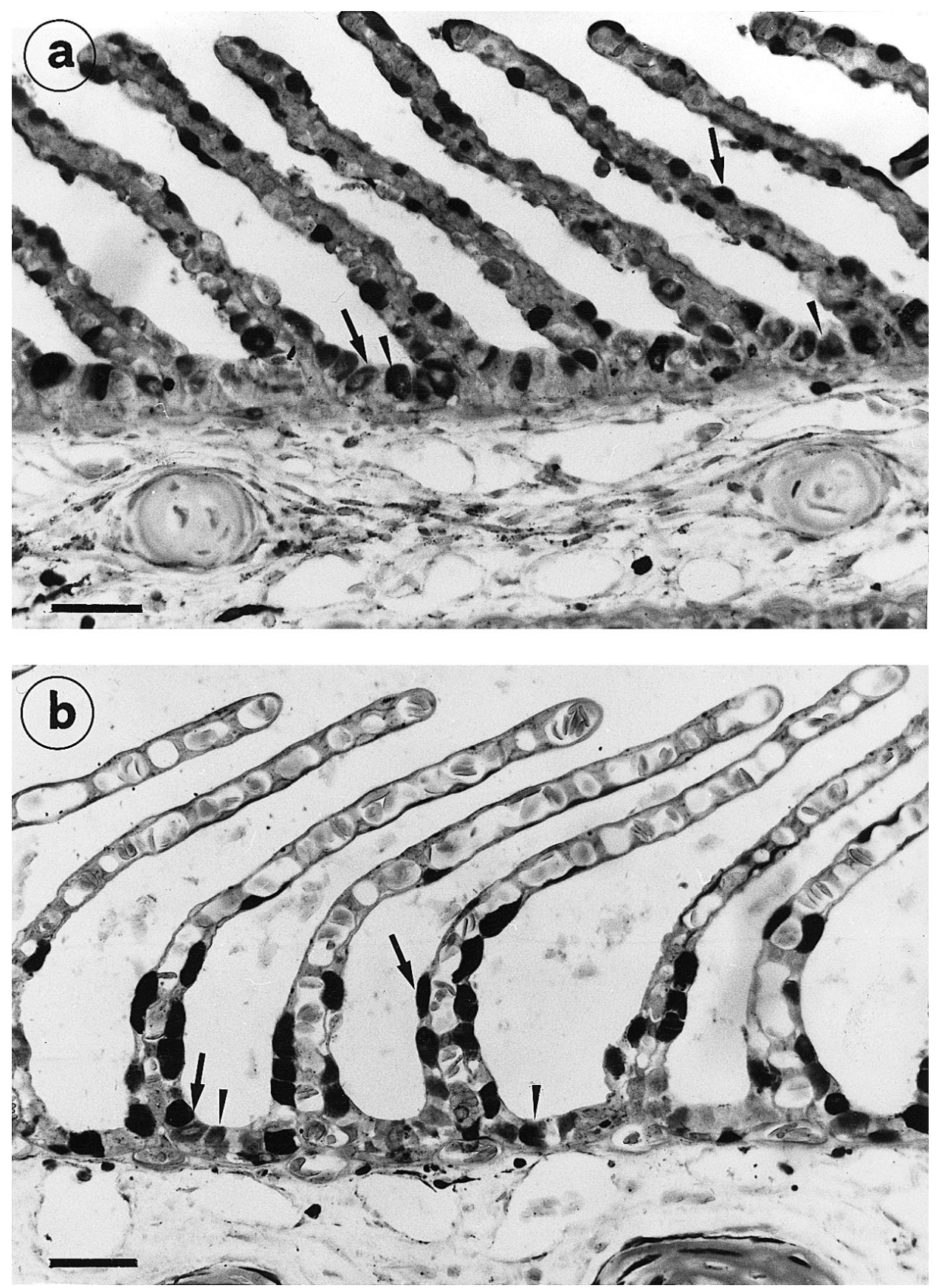

F IG. 2. Cross-section of gill filaments of A cipenser naccarii (a) living in fresh water, (b) acclimated to sea water from 60 days. A rrow indicates chloride cells contacting lamellar vessels, arrowhead indicates chloride cells extending towards the filament vessels. Scale bar, $50 \mu \mathrm{m}$.

for the euryhaline chondrosteans. In A. naccarii, variations in the number of chloride cells with salinity was evident only for the lamellar cells, both in BW and SW. 
T ABLE III. M ean numbers ( \pm S.D.) of chloride cells (Cc) on the lamellae $(\mathrm{L}, \mathrm{n}$ for each specimen $=168)$ and on the interlamellar spaces $(S, n$ for each specimen $=112$ ) in freshwater-, brackish water- and seawater-acclimated A. naccari in the two trials

\begin{tabular}{ccrc}
\hline & N o. of fishes & $\mathrm{CC} / \mathrm{L}$ & $\mathrm{Cc} / \mathrm{S}$ \\
\hline Trial 1 & & & \\
F W & 2 & $8.83 \pm 0.09$ & $0.76 \pm 0.24$ \\
BW & 2 & $6.68 \pm 0.21$ & $1.57 \pm 0.15$ \\
Trial 2 & & & \\
F W & 3 & $10.35 \pm 1.90$ & $1.30 \pm 0.12$ \\
BW & 2 & $7.22 \pm 0.48$ & $0.84 \pm 0.28$ \\
SW & 1 & $6.15 \pm 0.90$ & $1.50 \pm 0.55$ \\
\hline
\end{tabular}

According to $\mathrm{N}$ atochin et al. (1985), it is possible that sturgeons follow osmoregulatory mechanisms somewhat dissimilar from those of the teleosts. H owever, another conclusion can be drawn from the above preliminary observations: notwithstanding the fact that during the acclimation trials young A cipenser naccarii survived for a long period in SW, some features suggest an increasing difficulty to adapt. In fact serum osmolality increased with exposure to SW, and an osmotic imbalance is considered a symptom of ' non-adaptation ' (Franklin et al., 1992). The $20 \%$ salinity could represent the adaptability threshold for the Italian sturgeon as, when other stress factors, such as the non-optimal acclimation conditions of Trial 1, were added to osmotic stress osmotic imbalance emerged. U nfortunately, information concerning the biology of this species in the wild are scarce. This sturgeon may remain in estuarine brackish waters (Paccagnella, 1948), possibly enduring only brief excursions to the open sea.

On the other hand acclimation of young specimens of a single age class (1.5-2 yr old) does not allow detection of the presence of a possible smolting period, i.e. an exact period of the life cycle in which animals are physiologically prepared to adapt to salinity variations, as in salmonids (Boeuf, 1987). For young $A$. transmontanus $R$ ichardson an increased salinity tolerance with fish size has been observed, which is possibly related to ' maturational events' (M cEnroe $\&$ Cech, 1985).

Details of the patterns of osmoregulation in A. naccarii remain to be investigated.

This study was supported by a grant from EN EL s.p.a., contract N 0. 2R TPI0033. The authors are grateful to Dr L uigi F errucci for his help in the use of the Quantimet 970.

\section{R eferences}

A rlati, G., Bronzi, P., Colombo, L. \& G iovannini, G . (1988). Induzione della riproduzione nello storione italiano (A cipenser naccarii) allevato in cattività. Rivista I taliana di A cquacoltura 23, 94-96.

A vella, M ., Berhaut, J.\& Bornacin, M. (1993). Salinity tolerance of two tropical fishes, 0 reochromis aureus and 0 . niloticus. I. Biochemical and morphological changes in the gill epithelium. J ournal of Fish Biology 42, 243-254. 
Bernini, F . \& N ardi, P. A . (1990). A ccrescimento di A cipenser naccarii Bp. (Osteichthyes, A cipenseridae) nel tratto pavese dei F iumi Po e Ticino. Bollettino M useo regionale delle Scienze naturali di Torino 8, 159-172.

Boeuf, G . (1987). Bases physiologiques de la salmoniculture: osmoregulation et adaptation à l'eau de mer. Pisciculture Française 87, 28-40.

Bornacin, M ., A vella, M ., M asoni, A ., Sola, F . \& M ayer-G ostan, N . (1987). O smoregulation de la truite d'eau douce (Salmo gairdneri): importance de l'adaptibilité morpho-fonctionelle de l'epithelium branchial. 0 céanis 13, 71-87.

Cataldi, E., Crosetti, D., Leoni, C. \& Cataudella, S. (1988a). Oesophagus structure during adaptation to salinity in Oreochromis niloticus (Perciformes, Pisces) juveniles. Bollettino di Z oologia 55, 59-62.

Cataldi, E., Crosetti, D., Conte, G., D'Ovidio, D.\& Cataudella, S. (1988b). M orphological changes in the oesophageal epithelium during adaptation to salinities in 0 reochromis mossambicus, 0 . niloticus and their hybrid. J ournal of $F$ ish Biology 32, 191-196.

Cataldi, E., G aribaldi, L., Crosetti, D., Leoni, C. \& Cataudella, S. (1991). Variations in renal morphology during adaptation to salinities in tilapias. Environmental Biology of Fishes 31, 101-106.

Cataudella, S., A llegrucci, G ., Bronzi, P., Cataldi, E., Cioni, C., Corit, M ., Crosetti, D ., De M erich, D., Fortunato, C., G aribaldi, L., Loy, A., M arino, G., Sola, L. \& Sbordoni, V. (1991). M ultidisciplinary approach to the optimization of sea bass (Dicentrarchus labrax) rearing in freshwater. Basic morpho-physiology and osmoregulation. European A quaculture Society Special Publication 14, 56- 57.

Cioni, C., D e M erich, D., Cataldi, E.\& Cataudella, S. (1991). F ine structure of chloride cells in freshwater- and seawater-adapted Oreochromis niloticus (L innaeus) and O reochromis mossambicus (Peters). J ournal of Fish Biology 39, 197-209.

Colville, T. P., R ichards, R . H . \& D obbie, J. W . (1983). Variations in renal corpuscular morphology with adaptation to sea water in the rainbow trout, Salmo gairdneri $R$ ichardson. J ournal of Fish Biology 23, 451-546.

Dunel, S. \& Laurent, P. (1978). Functional organisation of the gill vasculature in different classes of fish. In E pithelial Transport in the L ower V ertebrates ( $L$ ahlou, A., ed.), pp. 37-58. London: Cambridge U niversity Press.

F ranklin, C. E., Forster, M . E . \& D avison, W. (1992). Plasma cortisol and osmoregulatory changes in sockeye salmon transferred to sea water: comparison between successful and unsuccessful adaptation. J ournal of Fish Biology 41, 113-122.

Gambaryan, S. P. (1988). K idney morphology in sturgeons: a microdissectional and ultrastructural study. J ournal of Fish Biology 33, 383-398.

G arcia-R omeu, F . \& M asoni, A . (1970). Sur la mise en évidence des cellules à chlorure de la branchie des poissons. Archives d'A natomie M icroscopique 59, 289-294.

H irano, T. (1974). Some factors regulating water intake by the eel, Anguilla japonica. J ournal of Experimental Biology 61, 737-747.

I wasaki, I., U tsami, S. \& Ozawa, T. (1952). N ew colorimetric determination of chloride using mercuric thiocyanate and ferric ion. Bulletin of the Chemical Society of J apan 25, 226-229.

K irsch, R., Humbert, W . \& Rodeau, J . L. (1984). Control of the blood osmolarity in fishes, with references to the functional anatomy of the gut. In 0 smoregulation in Estuarine and M arine A nimals (G illes, R. \& Gilles-Baillien, M ., ed.), pp. 67-92. Berlin: Springer.

K rayushkina, L. S., K iseleva, S. G. \& M oiseyenko, S. N. (1976). F unctional changes in the thyroid gland and the chloride cells of the gills during adaptation of the young Beluga sturgeon $\mathrm{H}$ uso huso to a hypertonic environment. J ournal of I chthyology $16,834-841$.

Lahlou, B., Henderson, I. W. \& Sawyer, W. H. (1969). Sodium exchanges in goldfish ( $C$ arassius auratus L.) adapted to a hypertonic solution. Comparative B iochemistry and Physiology 28, 1427-1433.

L aurent, P. \& D unel, S. (1980). M orphology of gill epithelia in fish. A merican J ournal of Physiology 238, 147-159. 
L aurent, P. \& H ebebi, N . (1989). Gill morphometry and fish osmoregulation. Canadian J ournal of Zoology 67, 3055-3063.

Laurent, P. \& Perry, S. F. (1991). Environmental effects on fish gill morphology. Physiological Zoology 64, 4-25.

M CEnroe, M . \& Cech, J. J. (1985). O smoregulation in juvenile and adult white sturgeon, A cipenser transmontanus. Environmental Biology of Fishes 14, 23-30.

N atochin, Y. V., L ukianenko, V. I., K irsanov, V. I., Lavrova, E. A., M etallov, G. F. $\&$ Shakhmatova, E. I. (1985). F eatures of osmotic and ionic regulation in R ussian sturgeon (A cipenser guldenstadti Brandt). Comparative Biochemistry and Physiology 80A, 297-302.

Oliverau, M . \& Oliverau, J . (1977). E ffect of transfer to sea water and back to fresh water on the histological structure of the eel kidney. J ournal of Comparative P hysiology $115,223-239$.

Paccagnella, B. (1948). Osservazioni sulla biologia degli storioni del Bacino Padano. A rchivi di O ceanografia e L imnologia 5, 141-154.

Potts, W. T. \& Rudy, P. P. (1972). A spects of osmotic and ionic regulation in the sturgeon. J ournal of Experimental Biology 56, 703-715.

R ochard, E., Castelnaud, G . \& L epage, M. (1990). Sturgeons (Pisces: A cipenseridae); threats and prospects. J ournal of Fish Biology 37 (Suppl. A), 123-132.

R ochard, E., W illiot, P., Castelnaud, G . \& L epage, M . (1991). Elements de systematique et de biologie des populations sauvages d'esturgeons. In A cipenser (W illot, P., ed.), pp. 475-507. Actes du premier colloque international sur l'esturgeon, Bordeaux, 3-6 octobre 1989. Bordeaux: CEM A GREF.

R ossi, R ., G randi, G ., Trisolini, R ., F ranzoi, P., Carrieri, A ., D ezfuli, B. S. \& V ecchietti, E. (1992). Osservazioni sulla biologia e la pesca dello storione cobice A cipenser naccarii Bonaparte nella parte terminale del fiume Po. A tti della Società I taliana di Scienze $N$ aturali e del M useo Civico di Storia Naturale di M ilano 132, 121-142.

Shelukhin, G. K., M etallov, G. F. \& G eraskin, P. P. (1990). Effect of temperature and salinity of Caspian sea water on juvenile R ussian sturgeon, A cipenser guldenstadti. J ournal of Ichthyology 30, 75-85.

Tortonese, E. (1989). A cipenser naccarii Bonaparte, 1836. In The Freshwater Fishes of E urope. General Introduction to Fishes. A cipenseriformes. Vol. I, Part II, (H olč̌k, J., ed.), pp. 285-293. W iesbaden: A U L A-Verlag.

Y amamoto, M.\& Hirano, T. (1978). M orphological changes in the esophageal epithelium of the eel, Anguilla japonica, during adaptation to sea-water. Cell and Tissue R esearch 192, 25-38.

Wendelaar Bonga, S. E. (1973). M orphometrical analysis with the light and electron microscope of the kidney of the anadromous three-spined stickleback Gasterosteus aculeatus, form trachurus, from fresh water and from sea water. Z eitschrift für Z ellforschung 137, 563-588. 